Article

\title{
Exploring and Quantifying River Thermal Response to Heatwaves
}

\author{
Sebastiano Piccolroaz ${ }^{1}\left({ }^{1}\right.$, Marco Toffolon ${ }^{2}{ }^{(0)}$, Christopher T. Robinson ${ }^{3,4}$ \\ and Annunziato Siviglia $5, *$ D \\ 1 Department of Physics and Astronomy, Institute for Marine and Atmospheric Research Utrecht, \\ Utrecht University, 3584 CC Utrecht, The Netherlands; s.piccolroaz@uu.nl or s.piccolroaz@unitn.it \\ 2 Department of Civil, Environmental and Mechanical Engineering, University of Trento, I-38123 Trento, Italy; \\ marco.toffolon@unitn.it \\ 3 Department of Aquatic Ecology, EAWAG, CH-8600 Düebendorf, Switzerland; \\ christopher.robinson@eawag.ch \\ 4 Department of Environmental Systems Science, Institute of Integrative Biology, ETH-Zürich, \\ CH-8092 Zürich, Switzerland \\ 5 Department of Civil, Environmental and Geomatic Engineering, Laboratory of Hydraulics, \\ Hydrology and Glaciology VAW, ETH Zürich, CH-8092 Zürich, Switzerland \\ * Correspondence: siviglia@vaw.baug.ethz.ch
}

Received: 22 May 2018; Accepted: 9 August 2018; Published: 17 August 2018

\begin{abstract}
Most of the existing literature on river water temperature focuseds on river thermal sensitivity to long-term trends of climate variables, whereas how river water temperature responds to extreme weather events, such as heatwaves, still requires in-depth analysis. Research in this direction is particularly relevant in that heatwaves are expected to increase in intensity, frequency, and duration in the coming decades, with likely consequences on river thermal regimes and ecology. In this study we analyzed the long-term temperature and streamflow series of 19 Swiss rivers with different hydrological regime (regulated, low-land, and snow-fed), and characterized how concurrent changes in air temperature and streamflow concurred to affect their thermal dynamics. We focused on quantifying the thermal response to the three most significant heatwave events that occurred in Central Europe since 1950 (July-August 2003, July 2006, and July 2015). We found that the thermal response of the analyzed rivers contrasted strongly depending on the river hydrological regime, confirming the behavior observed under typical weather conditions. Low-land rivers were extremely sensitive to heatwaves. In sharp contrast, high-altitude snow-fed rivers and regulated rivers receiving cold water from higher altitude hydropower reservoirs or diversions showed a damped thermal response. The results presented in this study suggest that water resource managers should be aware of the multiple consequences of heatwave events on river water temperature and incorporate expected thermal responses in adaptive management policy. In this respect, additional efforts and dedicated studies are required to deepen our knowledge on how extreme heatwave events can affect river ecosystems.
\end{abstract}

Keywords: heatwaves; river water temperature; thermal response of rivers; extreme climate events; hydrological regime; thermal regime; air temperature; climate change

\section{Introduction}

Air Temperature (AT) is generally thought to be one of the main controls of River Water Temperature (RWT) e.g., [1-4], motivating its use as a reasonable proxy to describe, although through simplified approaches, the physical dynamics that control river thermal regimes e.g., [5-7]. Although AT has been shown to be a very strong predictor of RWT, some studies have clearly demonstrated 
that it is not the only variable influencing river thermal dynamics. In some cases a key role is also played by streamflow (SF) e.g., [8-12]. This aspect becomes relevant when the aim is to predict how water temperature in a river will respond in the future, specifically because projected increases in AT are expected to be compounded with substantial changes in total annual precipitation [13]. In addition, Krasting et al. [14] estimated that snowfall will likely decrease throughout the entire snowfall season in the Northern Hemisphere, especially at the mid-latitude regions. Alterations in snowpack accumulation and timing of spring snowmelt will undeniably affect river thermal regimes. In fact, snow-dominated rivers are generally thermally buffered by snowmelt in summer, due to upstream advective fluxes of cold water that can overwhelm the warming effect resulting from increasing AT in summer e.g., [15-17]. A similar damping of RWT can also be visible in cold headwater streams $[18,19]$ that are generally less directly coupled to atmospheric energy exchanges, and in rivers that are dominated by deep and cold groundwater inflows [20,21], whose temperature is in turn linked to climate and land use conditions [22]. Along with the central role exerted by climatic and hydrological factors, a number of studies have also shown that human disturbances such as modifications in land use e.g., [23], changes in riparian vegetation e.g., [24,25] (also associated with the occurrence of wildfires [8]), presence of large reservoirs and lakes [26,27], damming e.g., [28-31], and thermal releases [32] can strongly contribute in controlling RWT dynamics e.g., [33].

The thermal regime of a river is therefore mediated by the overall complexity of the hydrological, climate, and land-use features of its watershed, thus making the significance and magnitude of changes in RWT relative to changes in AT inherently site-specific [17,34]. In this regard, Kelleher et al. [35] introduced the concept of thermal sensitivity (successively developed by Mayer [36]), defined as the sensitivity of RWT at a given site to changes in AT, and quantified as the slope of the regression line between AT and RWT. Piccolroaz et al. [37] revisited and extended this concept by introducing a new classification that distinguishes between thermally reactive and thermally resilient rivers. The authors found a strong correlation between their new thermal classification and the hydrological regime of rivers.

Since RWT is an ultimate driver of the ecology of streams and rivers, dictating the overall health and integrity of aquatic ecosystems [4], a proper understanding of the sensitivity of RWT to fluctuations in climate is of considerable interest to water resource managers [33] and freshwater ecologists [38]. The present study is intended to contribute to the advancement of such understanding, complementing the existing literature on river thermal regimes by specifically exploring and quantifying the response of RWT to extreme pulse events such as heatwaves, namely extended periods of unusually high atmosphere-related heat stress generally compounded by extraordinary dry periods [39]. The motivation behind this study is two-fold. First, most of the existing literature focused on the response of RWT to long-term trends of climate variables, while how RWT responds to extreme events still requires in-depth analysis. For instance, recent works have shown that - coherently with a gradual AT warming trend observed during the last century-several rivers are experiencing long-term warming trends e.g., [8,40-43] (although with different significance and magnitude depending on the specific site characteristics). However, these studies did not analyze the thermal response to the occurrence of abnormal climatic conditions. Second, and related to the previous point, observations and predictions indicate that climate extremes, including heatwaves, will increase in frequency, intensity and duration globally in the coming next decades [44-47], suggesting the need to consider a change of paradigm in scientific research from trend-focused to trend- and event-focused studies [48].

We note that heatwaves are expected to have serious non-linear effects on aquatic ecosystems [38], potentially causing a breakdown and loss in ecosystem function and composition [49,50], and favoring invasive species because of differences in tolerance and abilities to preempt available resources (e.g., by growth and colonization) more quickly than native species [51]. For example, the 2003 European heatwave caused high mortality among riverine benthic invertebrates in France and major shifts in density and species richness that lasted for almost a decade [52,53]. This undoubtedly offers 
further confirmation of the need to deepen our understanding of how RWT responds to extreme weather events.

In this study, we used the instrumental record of 19 gauged river stations of the Swiss monitoring network to assess the thermal response of three different hydrological categories of rivers (namely: regulated by higher altitude hydropower reservoirs or diversions, low-land without anthropogenic flow releases from higher altitudes, and glacier/snow-fed) to varying AT and SF during a 32-year period. The study period (1984-2015) contained the occurrence of the three most significant heatwaves that occurred in Central Europe since 1950 (June-August 2003, July 2006, and July 2015 [54]), which were analyzed to disentangle how concurrent changes in AT and SF affected the thermal response of the different river categories under extreme climatic conditions. The considered dataset covers an Alpine region characterized by a large variability in orographic, land-use, hydrological, and climatic features, thus allowing for generalization of the results to other similar contexts.

\section{Materials and Methods}

\subsection{Available Data}

The available dataset comprised 19 Swiss stations, evenly distributed within the Swiss region (Figure 1 and Table 1). Since the 1960s, RWT at sites has been measured throughout Switzerland continuously using platinum resistance recorders [55]. High accuracy of temperature measurements $\left( \pm 0.15{ }^{\circ} \mathrm{C}\right)$ is guaranteed by periodic and regular comparative measurements with calibrated thermometers [56]. For each station, we used data for RWT and SF at intervals of 10 and $15 \mathrm{~min}$, respectively, from which we calculated daily averages. The record of observations for each station is specified in Table 1, which contains 24 rivers (five were not considered in the main part of the analysis because the temporal record was shorter). Data were obtained by the Swiss Federal Office of the Environment (BAFU).

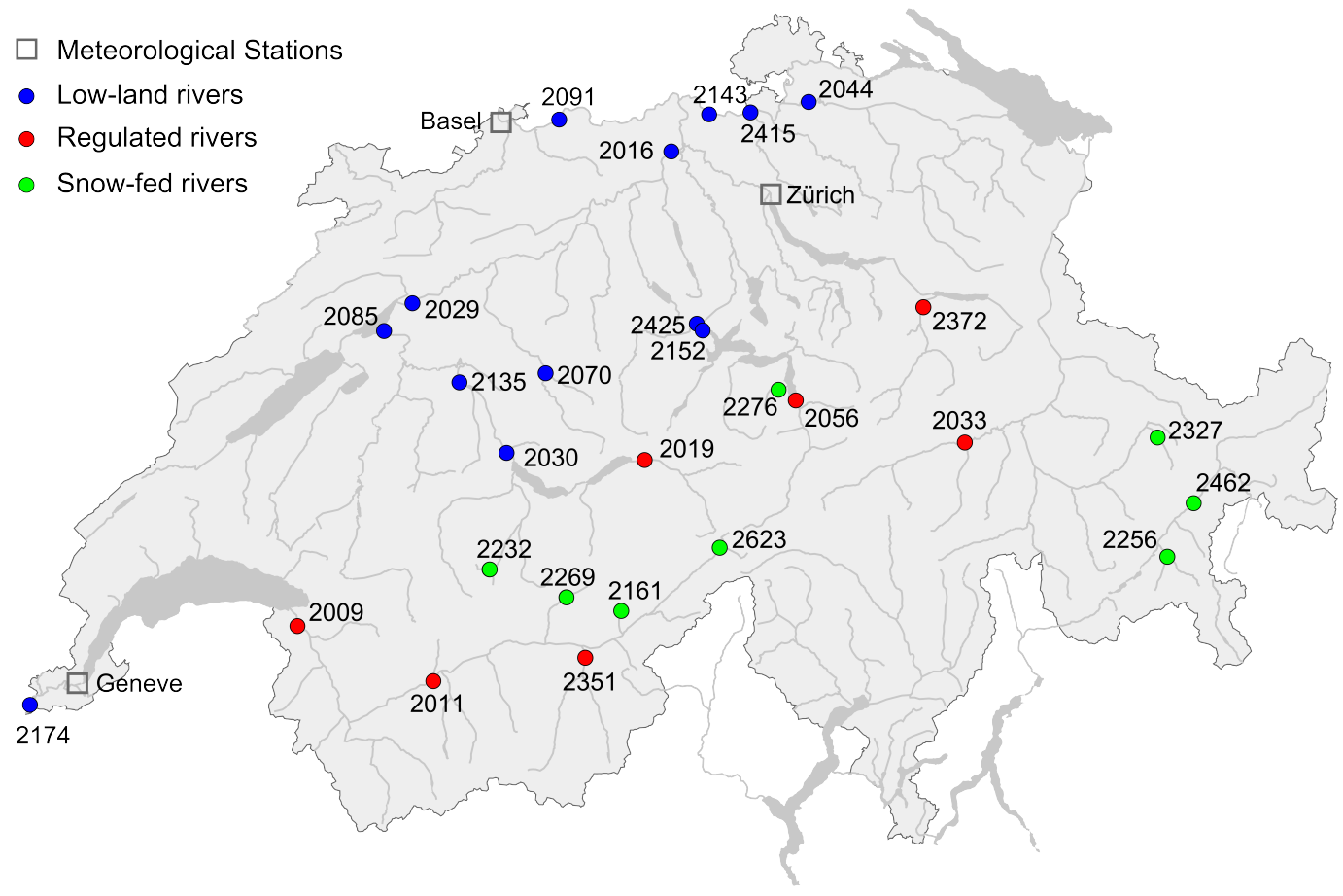

Figure 1. Map of Switzerland with the location of river stations (ID numbers, see Table 1) and meteorological stations used in the analysis. 
Table 1. Dataset of Swiss river stations used in the analysis. In italics we refer to snow-fed river stations with a RWT record shorter than 30 years, which were used only in the analysis presented in Figure 8.

\begin{tabular}{|c|c|c|c|c|c|c|c|c|c|}
\hline \multirow{2}{*}{ ID } & \multirow{2}{*}{ River } & \multirow{2}{*}{ Station } & \multirow{2}{*}{$\begin{array}{l}\text { Station } \\
\text { (m a.s.l.) }\end{array}$} & \multirow{2}{*}{ Elevation } & \multirow{2}{*}{$\begin{array}{l}\text { Surface Area of } \\
\text { Catchment }\left(\mathrm{km}^{2}\right)\end{array}$} & \multirow{2}{*}{$\begin{array}{l}\text { Mean Elevation of } \\
\text { Catchment ( } m \text { a.s.1.) }\end{array}$} & \multirow{2}{*}{$\begin{array}{l}\text { Distance from Hydropower } \\
\text { Release }{ }^{* *}(\mathrm{~m})\end{array}$} & \multicolumn{2}{|c|}{ Record of Observation * } \\
\hline & & & & & & & & RWT & Streamflow \\
\hline \multicolumn{10}{|c|}{ Low-land rivers } \\
\hline 2016 & Aare & Brugg & 332 & & 11,726 & 1010 & - & 1984-2015 & 1984-2015 \\
\hline 2029 & Aare & Brügg, Aegerten & 428 & & 8293 & 1150 & - & $1984-2015$ & $1984-2015$ \\
\hline 2030 & Aare & Thun & 548 & & 2466 & 1760 & - & $1984-2015$ & $1984-2015$ \\
\hline 2044 & Thur & Andelfingen & 356 & & 1696 & 770 & - & $1984-2015$ & $1984-2015$ \\
\hline 2070 & Emme & Emmenmatt & 638 & & 443 & 1069 & - & $1984-2015$ & $1984-2015$ \\
\hline 2085 & Aare & Hagneck & 437 & & 5104 & 1380 & - & $1984-2015$ & $1984-2015$ \\
\hline 2091 & Rhein & Rheinfelden & 262 & & 34,526 & 1039 & - & $1984-2008,2011-2015$ & $1984-2015$ \\
\hline 2135 & Aare & Bern, Schönau & 502 & & 2945 & 1610 & - & $1984-2015$ & 1984-2015 \\
\hline 2143 & Rhein & Rekingen & 323 & & 14,718 & 1080 & - & $1984-2015$ & $1984-2015$ \\
\hline 2152 & Reuss & Luzern, Geissmattbrücke & 432 & & 2251 & 1500 & - & $1984-2015$ & $1984-2015$ \\
\hline 2174 & Rhône & Chancy, Aux Ripes & 336 & & 10,323 & 1580 & - & 1984-2015 & $1984-2015$ \\
\hline 2415 & Glatt & Rheinsfelden & 336 & & 416 & 498 & - & 1984-2015 & 1984-2015 \\
\hline \multicolumn{10}{|c|}{ Regulated rivers } \\
\hline 2009 & Rhône & Porte Du Scex & 377 & & 5244 & 2130 & 26,510 & 1984-2015 & 1984-2015 \\
\hline 2011 & Rhône & Sion & 484 & & 3373 & 2310 & 9300 & $1984-2015$ & $1984-2015$ \\
\hline 2019 & Aare & Brienzwiler & 570 & & 554 & 2150 & 11,770 & $1984-2015$ & $1984-2015$ \\
\hline 2056 & Reuss & Seedorf & 438 & & 832 & 2010 & 39,670 & $1984-2015$ & $1984-2015$ \\
\hline 2372 & Linth & Mollis, Linthbrücke & 436 & & 600 & 1730 & 5600 & 1984-2015 & $1984-2015$ \\
\hline \multicolumn{10}{|c|}{ Snow-fed rivers } \\
\hline 2269 & Lonza & Blatten & 1520 & & 77.8 & 2630 & - & 2/11/1986-2015 & 1984-2015 \\
\hline 2462 & Inn & S-chanf & 1645 & & 618 & 2466 & - & $1984-2015$ & 25/3/1999-2015 \\
\hline 2161 & Massa & Blatten bei Naters & 1446 & & 195 & 2945 & - & 2003-2015 & 1984-2015 \\
\hline 2232 & Allenbach & Adelboden & 1297 & & 28.8 & 1856 & - & $2002-2015$ & $1984-2015$ \\
\hline 2256 & Rosegbach & Pontresina & 1766 & & 66.5 & 2716 & - & 2004-2015 & $1984-2015$ \\
\hline 2276 & Grosstalbach & Isenth & 767 & & 43.9 & 1820 & - & 19/2/2004-2015 & $1984-2015$ \\
\hline 2327 & Dischmabach & Davos, Kriegsmatte & 1668 & & 43.3 & 2372 & - & 27/12/2003-2015 & $1984-2015$ \\
\hline
\end{tabular}

Note: ${ }^{*}$ The intervals refer to the period from 1 January of the first year to 31 August 2015, if not otherwise specified. ${ }^{* *}$ According to Vanzo et al. [57]. 
Using available GIS information (https:/ / map.geo.admin.ch) and expert judgement, Piccolroaz et al. [37] analyzed 38 Swiss gauging stations and classified them into groups of rivers with different hydrological regimes depending on different geomorphic and anthropogenic characteristics of the river catchments. In this study, we used that same classification, extending the analysis to some river stations not considered in that work but present in our dataset. The first group (referred to as 'regulated') was characterized by rivers flowing along mountain valley floors with upstream releases from bottom withdrawals from higher altitude storage hydropower plants, hydraulic diversions, or any other anthropogenic regulations introducing a shortcut between high altitudes and valley bottoms. Water releases were located at a variable distance from the monitored cross section (see Table 1). The second group (referred to as 'low-land' rivers) was not affected by anthropogenic flow releases able to alter the thermal pattern and was characterized by low altitude and large catchment areas. This group also comprised lake outlets and rivers with hydraulic structures for hydroelectricity production, but only of the run-of-the-river type. The third group (referred to as 'snow-fed') comprised natural rivers at high altitude and at short distance downstream of a glacier or snowfield (as indicated by the high altitudes of the stations and small areas of the river catchments in Table 1, compared to the other two groups), which directly contribute to streamflow through their melting waters.

Piccolroaz et al. [37] verified the robustness of this GIS-based classification by analyzing the typical seasonal patterns of RWT, AT and SF, which showed markedly different features among the considered hydrological classes. This result provided the basis to introduce a river classification to distinguish between thermally reactive rivers (low-land rivers) and thermally resilient rivers (regulated and glacier/snow-fed rivers). We remark that this classification may differ from other classifications specifically intended to investigate high frequency hydro- and thermo-peaking e.g., [57-60], where the time scale of interest was sub-daily. We also note that in the original classification, Piccolroaz et al. [37] considered low-land rivers and lake outlets as belonging to two different river categories. Here we opted to combine these two river categories together since, as will be discussed later, preliminary analysis showed fully comparable thermal response to extreme events.

AT patterns in this study were based on daily averaged air temperatures recorded in the period 1984-2015 in some representative stations on the Swiss Plateau (see the next section for details). Data were obtained from the Swiss Meteorological Institute (MeteoSchweiz).

\subsection{Statistical Analysis}

For each analyzed variable (i.e., AT, RWT, and SF) and each river station, a climatological year was defined by averaging for each day of the year the values of all measurements available over the observation period for that same day (see Table 1). The climatological years for AT, RWT and SF (namely $\overline{A T}, \overline{R W T}$, and $\overline{S F}$ ) were defined using the period with overlap of the three variables. We note that a 30-year period is generally accepted as a suitable time window to construct a climatological year e.g., [61], and that in nearly all the 19 stations considered here, a 32-year observational period was available (only in two cases a 30-year record was available for RWT and a 17-year for SF; in the latter case, the station was excluded from the analysis of SF anomalies; see Table 1).

Daily temperature anomalies of both RWT and AT were then calculated as the difference in the temperature value $\left(T_{y, i}\right)$ in a day with respect to the climatological year $\left(\bar{T}_{i}\right)$

$$
T \prime_{y, i}=T_{y, i}-\bar{T}_{i}
$$

where / indicates anomalies, the subscript $i$ denotes the generic $i$-th day of year $y$, and $T$ is the generic variable standing either for RWT or AT. Differently from above, and to deal with possible larger variability of SF among rivers and seasons, SF anomalies were normalized relative to the climatological year as follows

$$
q_{y, i}^{\prime}=\frac{Q^{\prime}{ }_{y, i}}{\bar{Q}_{i}}=\frac{Q_{y, i}-\bar{Q}_{i}}{\bar{Q}_{i}}=q_{y, i}-1
$$


where $Q$ and $q$ are SF and normalized SF (dimensionless), respectively.

The use of temperature anomalies is a common and consolidated practice to describe inter-annual variability in climate change studies e.g., [62,63], including those focused on extreme events such as heatwaves e.g., [64]. The reason (and need) to use temperature anomalies instead of absolute temperatures is that the former provides a frame of reference that allows for a fair comparison among data that are spatially distributed. Conversely, absolute temperatures are inherently affected by local factors (such as the location and elevation of the measurement site), thus may vary significantly even over short distances. Hence, comparing absolute temperatures may not be possible, while there is a strong correlation between temperature anomalies over large distances e.g., $[65,66]$. Since the interest here is on investigating the effect of large scale (macro-regional) climatic events (i.e., heatwaves), in this study we evaluated the AT anomalies by averaging the data from a few meteorological stations on the Swiss Plateau (Zurich, Basel and Geneva), which covered the whole analyzed period. The computed anomalies can be safely considered as representative of the inter-annual variability at the regional scale (i.e., the time and spatial scales of interest) [60]. This is in agreement with Hari et al. [40], which showed that measurements from a few stations on the Swiss Plateau effectively capture the temporal structure in regional air temperatures, and with Schär et al. [64], who considered these stations as particularly reliable and suggested to amalgamate the data into one single series to minimize the contamination by local meteorological and instrumental conditions.

Probability distributions of daily anomalies of AT, RWT, and SF were calculated for the two summer periods June-July-August (JJA, i.e., 92 days) and July (J, i.e., 31 days), when 2003, 2006, and 2015 heatwaves were particularly intense [54]. Three empirical probabilistic distributions were defined, one for each river group, by joining the daily anomalies of AT, RWT, and SF from all years and river stations in the dataset, limited to the periods JJA and J. This allowed us to locate the relative importance of heatwave events in the range of climatological variations.

Finally, to quantify the cumulative stress of RWT changes on aquatic biota, we used the degree-days (DD) of temperature anomalies defined as the integral of RWT anomalies over time (i.e., the area under the curve of the temperature anomalies). DD is an index generally used to assess the relationships between cumulative temperature measures and ecological processes [67-69]. In addition, DD was calculated for the periods JJA and J.

\section{Results}

According to Russo et al. [54], heatwaves that occurred in July-August 2003, July 2006, and July 2015 were the three most significant heatwave events that occurred in Central Europe since 1950. The 2003 heatwave event was the strongest, the 2006 event the weakest, while the 2015 heatwave was intermediate to these but particularly significant in Switzerland [54].

Figure 2 shows the distributions of daily anomalies of AT and RWT during the summer period July-August (JJA) and the corresponding mean daily anomaly relative to the same period (indicated with an arrow) for each river category (subplots A, C, E, and G). The number of days (and consecutive days) exceeding the 90th percentile for AT and RWT anomalies are also shown for each year, providing a quantitative measure of the intensity of the corresponding anomalies (subplots $\mathrm{B}, \mathrm{D}, \mathrm{F}$, and $\mathrm{H}$ ). The 2003 heatwave event is clearly identifiable (Figure 2B). The seasonally averaged daily AT anomaly in JJA-2003 was approximately equal to the 90th percentile of the climatological (i.e., 30-year long-term) distribution of JJA daily anomalies (Figure 2A), with nearly 50 days (i.e., $55 \%$ of the JJA period) warmer than this threshold being evident (including 17 consecutive days, Figure 2B). Low-land rivers were strongly affected by this extreme event, to the extent that RWT response was even amplified when compared to AT, with the seasonally averaged daily RWT anomaly being greater than the 90th percentile (Figure 2C) and more than 60 days (i.e., $65 \%$ of the JJA period) warmer than this threshold being evident (Figure 2D), among which 22 consecutive days. This result was not observed for regulated and snow-fed rivers in which the seasonally averaged daily anomaly in JJA was just slightly above the distribution median (Figure 2C,E,G). In these two groups, no clear difference in 
the number of days above the threshold was visible during the occurrence of the 2003 heatwave with respect to the other years (Figure 2D,F,H).
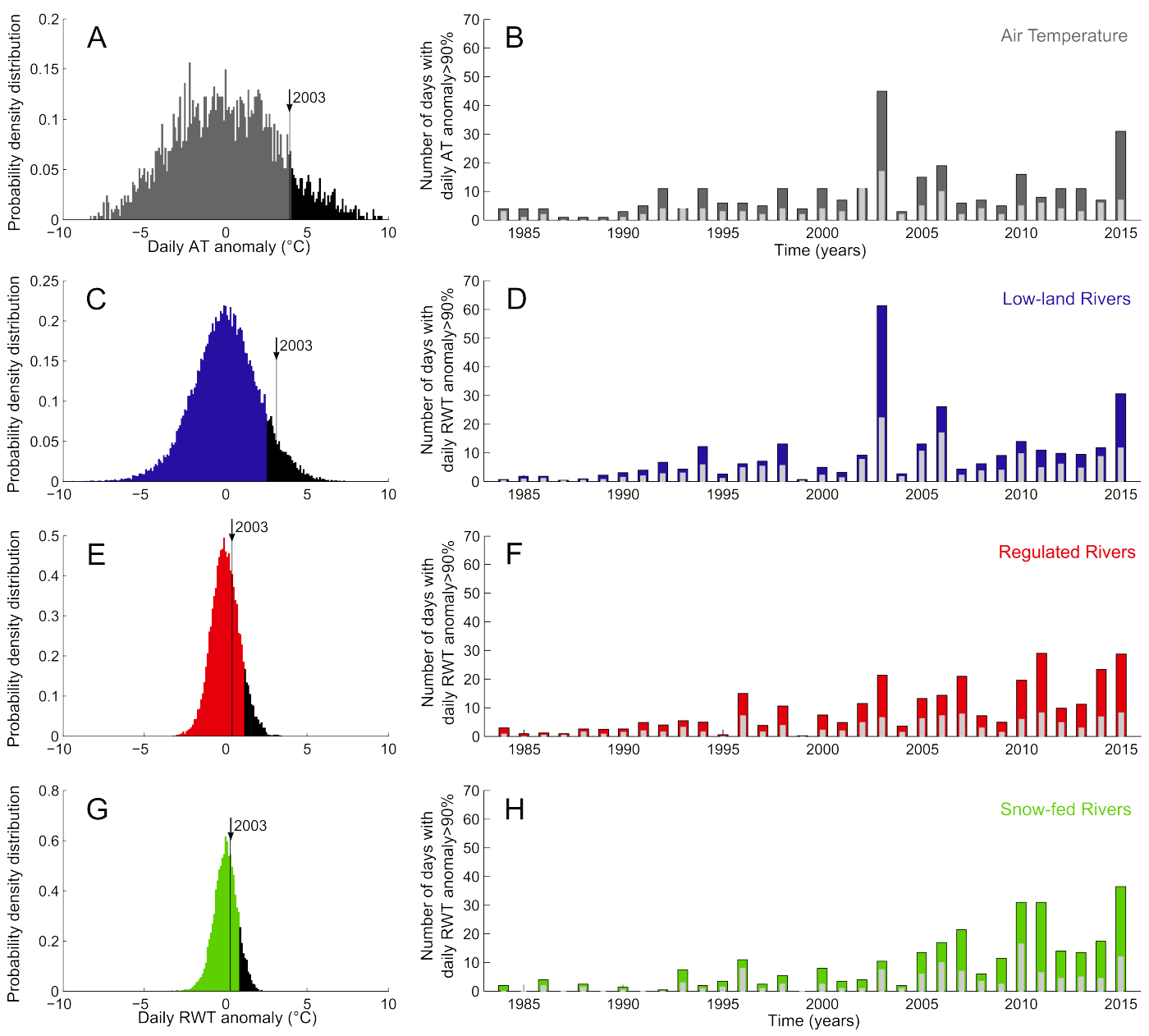

Figure 2. Distributions of daily anomalies during the summer period JJA, considering air temperature (A) and water temperature for low-land (C), regulated (E) and snow-fed (G) rivers. Shaded areas show the top 90th percentile in the distribution and arrows indicate the averaged anomalies for the strong heatwave in 2003. The number of days exceeding $90 \%$ is shown in the right column $(\mathbf{B}, \mathbf{D}, \mathbf{F}, \mathbf{H})$ for the period 1984-2015, with inset bars indicating the number of consecutive days.

During the 2003 heatwave, low-land rivers experienced a decrease in streamflow (Figure 3A). However, the streamflow anomaly in JJA was not so strong, since the seasonally averaged daily anomaly stayed above the 10th percentile of the climatological distribution of JJA anomalies (Figure 3A), with less than 30 days (i.e., $33 \%$ of the JJA period) below the 10th percentile (including 11 consecutive days, Figure 3B). Conversely, no streamflow reduction was experienced by the other two groups in the same period (Figure 3C,E). On the contrary, the class of snow-fed rivers was the only group with positive streamflow anomalies (Figure 3), suggesting that heatwave events may actually increase meltwater inputs from glaciers/snowfields. In turn, this may even cause cooling of RWT, as observed in several boreal streams in southwest Alaska [17]. The small number of snow-fed rivers with long-term data (see Table 1), however, did not allow for further deepening the analysis of this river category.

Analogous results, albeit less pronounced, emerged from the analysis of the shorter 2006 and 2015 July heatwaves (Figures 4 and 5). This is especially true for low-land rivers, which, as in 2003, showed a marked response of RWT accompanied by moderate flow reduction. However, during these two heatwaves events, regulated and snow-fed rivers experienced a stronger response of RWT to positive AT anomalies, especially snow-fed rivers in 2015. Interestingly, in these cases positive RWT 
anomalies were not associated with any remarkable flow reduction (the monthly averaged daily SF anomalies being slightly negative or close to the median for both river categories), as confirmed by the small numbers of days with daily SF anomalies below the 10th percentile. In other words, RWT warmed irrespective of the fact that the thermal inertia of the rivers at hand did not undergo a notable reduction due to flow decrease, suggesting a secondary and, in some respects, complex role of SF on thermal sensitivity of rivers.

We extended the analysis of thermal and flow response of rivers to extreme AT events to the entire 32-year time series by performing correlation analysis between the number of warm AT and RWT days (i.e., temperature anomalies warmer than the 90th percentile) and the number of low flow days (SF anomalies lower than the 10th percentile). Results in terms of the Pearson correlation coefficient $R$ and significance $p$-value are listed in Table 2 for the different river categories, analyzed periods (JJA and J), and pairs of variables. The results revealed statistically significant ( $p$-value $<0.01$ ) and very strong positive correlation ( $\mathrm{R} \sim 0.95$ ) between AT and RWT warm days in low-land rivers, both in JJA and J. A statistically significant but much lower correlation was found for the other two river categories ( $R=0.61$, on average). On the contrary, the correlation between the number of warm AT days and low flow days, showed statistically significant results only for low-land rivers $(R=0.67$, on average) but not for the other two river categories, confirming the complete disconnection between extreme AT and low flow events in regulated and snow-fed rivers. Similarly, the correlation between RWT warm days and low flow days showed good correlation $(R=0.72$, on average) only for low-land rivers, while it was low and in general not significant for the other two categories (especially for snow-fed rivers), corroborating the unclear role of SF on the thermal sensitivity of these rivers.
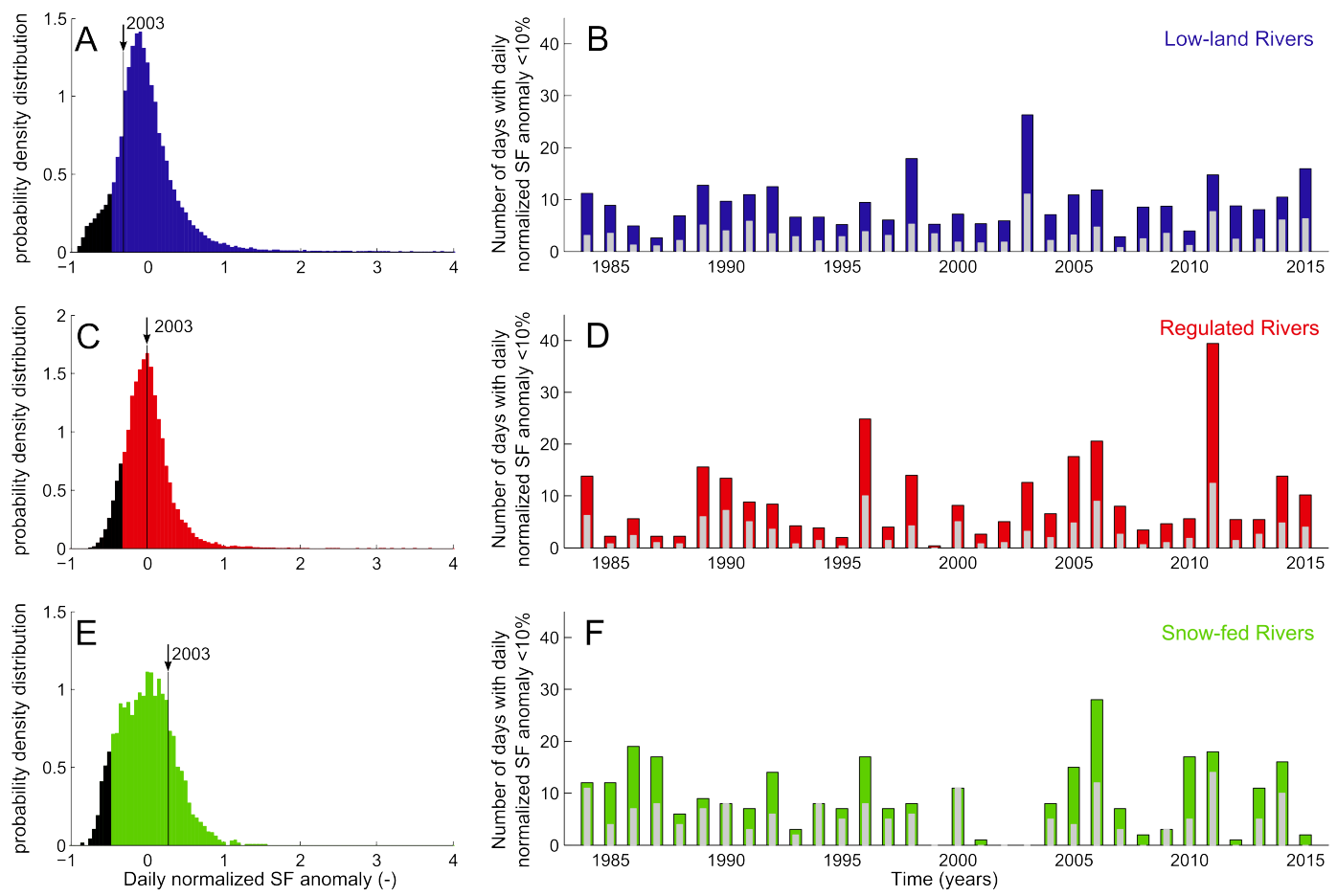

Figure 3. Distributions of daily anomalies in normalized streamflow for low-land (A), regulated (C) and snow-fed (E) rivers during JJA. Shaded areas show the bottom 10th percentile in the distribution and arrows indicate the averaged anomalies for the heatwave in 2003. The number of days below $10 \%$ is shown in the right column $(\mathbf{B}, \mathbf{D}, \mathbf{F})$ for the period 1984-2015, with inset bars indicating the number of consecutive days. 

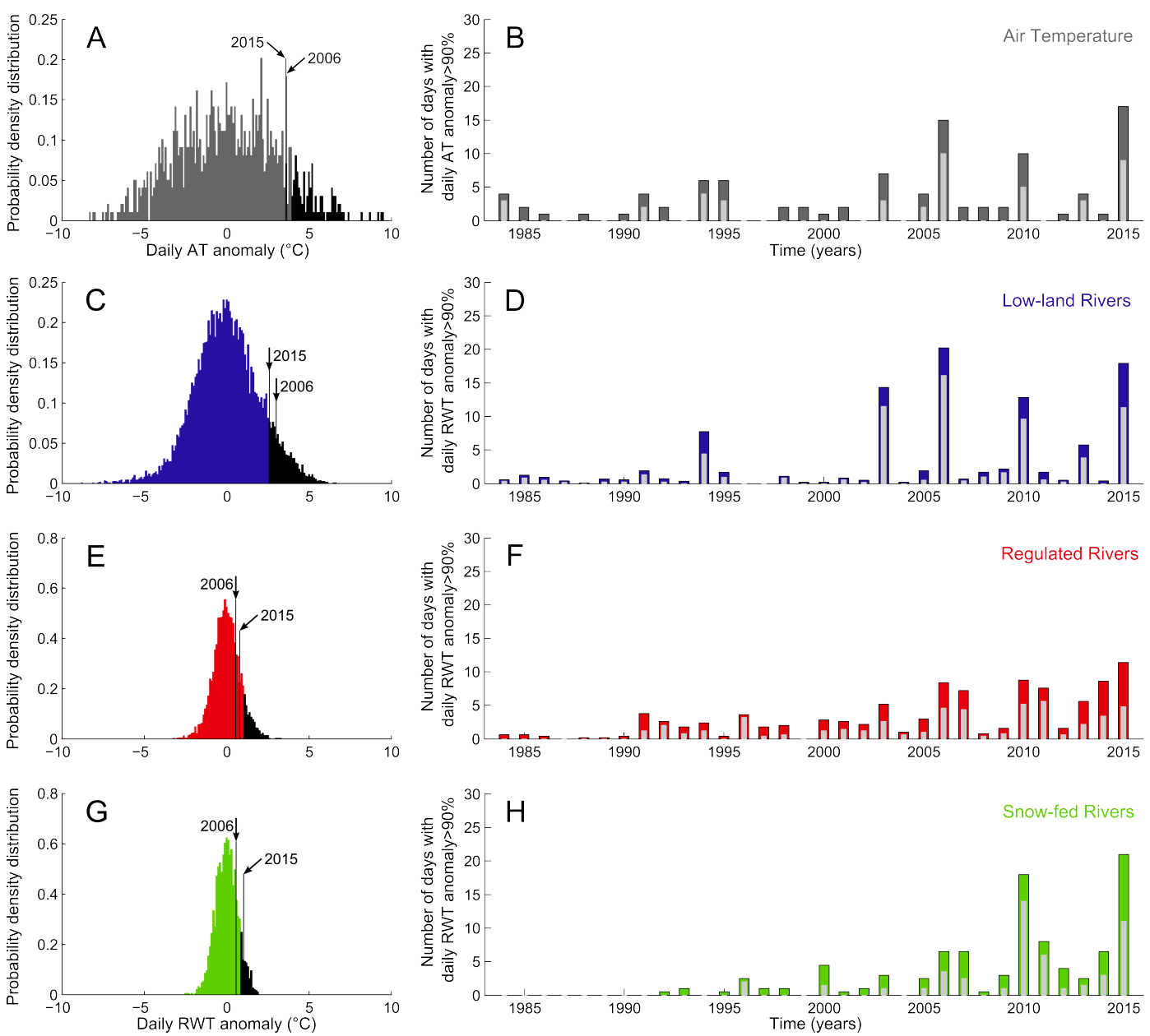

Figure 4. Distributions of daily anomalies during July, considering air temperature (A) and water temperature for low-land $(\mathbf{C})$, regulated $(\mathbf{E})$ and snow-fed $(\mathbf{G})$ rivers. Shaded areas show the top 90th percentile in the distribution and arrows indicate the averaged anomalies for the two heatwaves in 2006 and 2015. The number of days exceeding $90 \%$ is shown in the right column $(\mathbf{B}, \mathbf{D}, \mathbf{F}, \mathbf{H})$ for the period 1984-2015, with inset bars indicating the number of consecutive days.

Table 2. Results from correlation analysis (Pearson correlation coefficient $R$, and significance level $p$ of the F test) between the 32-year time series of AT and RWT warm days (i.e., temperature anomalies warmer than the 90th percentile) and low flow days (i.e., SF anomalies lower than the 10th percentile). Results are listed for the different river categories, analyzed periods (JJA and J), and pairs of variables (AT vs. RWT, AT vs. SF, RWT vs. SF). Correlation is considered statistically significant for $p$-value $<0.01$.

\begin{tabular}{lccccccc}
\hline & \multicolumn{2}{c}{ AT vs. RWT } & \multicolumn{2}{c}{ AT vs. SF } & \multicolumn{2}{c}{ RWT vs. SF } \\
\cline { 2 - 7 } & $\begin{array}{l}\boldsymbol{R} \\
(-)\end{array}$ & $\begin{array}{c}\boldsymbol{p} \text {-Value } \\
(-)\end{array}$ & $\begin{array}{c}\boldsymbol{R} \\
(-)\end{array}$ & $\begin{array}{c}\boldsymbol{p} \text {-Value } \\
(-)\end{array}$ & $\begin{array}{c}\boldsymbol{R} \\
(-)\end{array}$ & $\begin{array}{c}\boldsymbol{p} \text {-Value } \\
(-)\end{array}$ \\
\hline Low-land rivers & & & & & & & \\
JJA & 0.96 & $<0.01$ & 0.68 & $<0.01$ & 0.75 & $<0.01$ \\
J & 0.93 & $<0.01$ & 0.66 & $<0.01$ & 0.69 & $<0.01$ \\
Regulated rivers & & & & & & \\
JJA & 0.62 & $<0.01$ & 0.18 & 0.32 & 0.58 & $<0.01$ \\
J & 0.64 & $<0.01$ & 0.07 & 0.71 & 0.42 & 0.02 \\
Snow-fed rivers & & & & & & \\
JJA & 0.49 & $<0.01$ & -0.11 & 0.53 & 0.20 & 0.26 \\
J & 0.67 & $<0.01$ & -0.26 & 0.15 & 0.13 & 0.48 \\
\hline
\end{tabular}



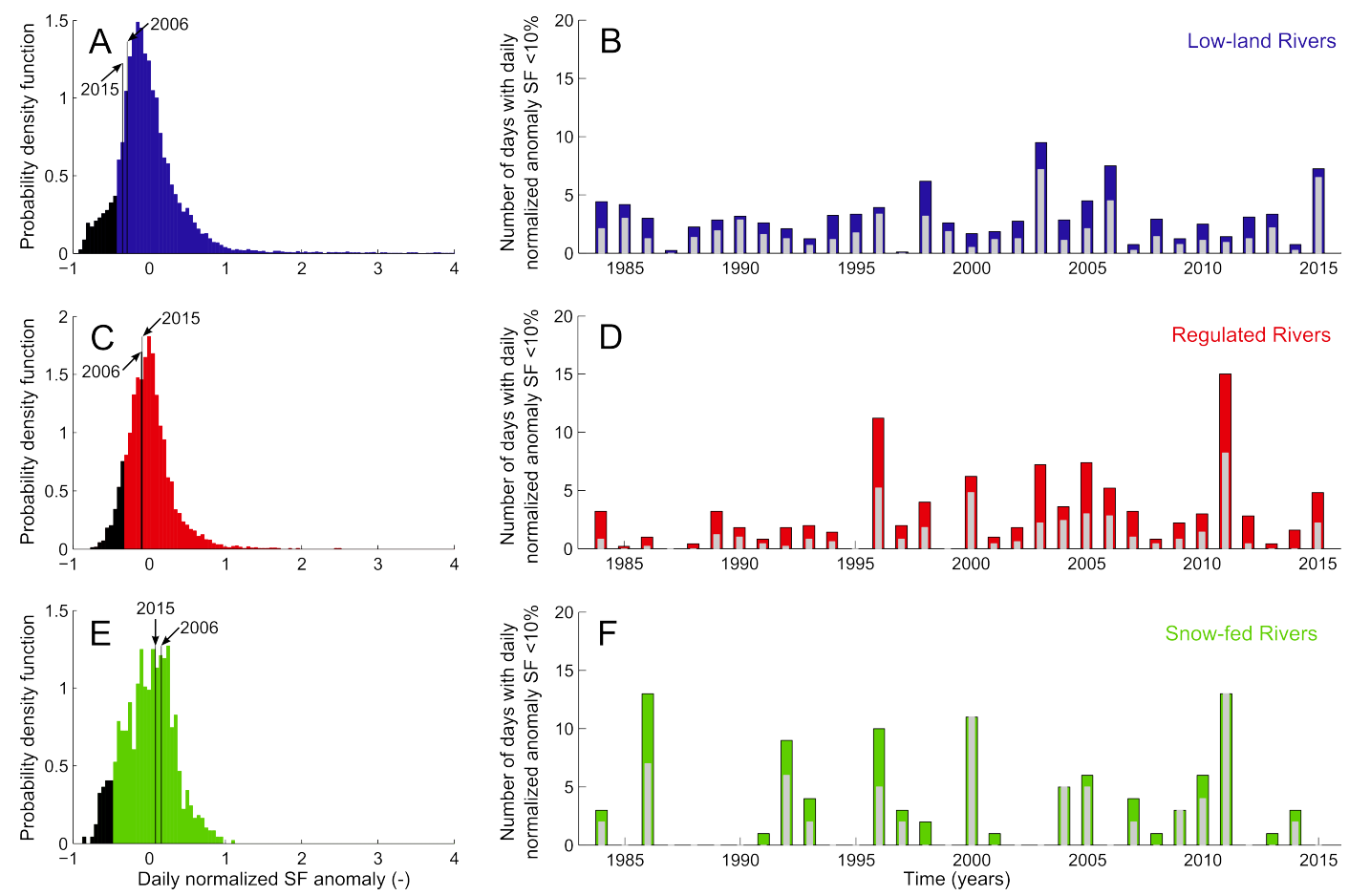

Figure 5. Distributions of daily anomalies in normalized streamflow for low-land (A), regulated (C) and snow-fed (E) rivers during July. Shaded areas show the bottom 10th percentile in the distribution and arrows indicate the averaged anomalies for the heatwaves in 2006 and 2015. The number of days below $10 \%$ is shown in the right column $(\mathbf{B}, \mathbf{D}, \mathbf{F})$ for the period 1984-2015, with inset bars indicating the number of consecutive days.

Since the standard deviation of RWT anomalies for regulated and snow-fed rivers (less than $0.8^{\circ} \mathrm{C}$ ) was lower than that of low-land rivers (about $2.0^{\circ} \mathrm{C}$, see also the empirical distribution function in Figures 2 and 4), the occurrence of RWT anomalies above a given percentile threshold is expected to have different impacts on aquatic life in the three river categories. In order to address this point and coherently with existing literature in the field of freshwater biology e.g., [67-69], we introduced the cumulated degree days of anomalies (DD) as an useful indicator to quantify the response of a river to a heatwave event and the resulting impact on freshwater ecosystem. During the 2003 heatwave (JJA), the DD at the end of August reached nearly 290 DD in low-land rivers, ca. 35 DD in regulated rivers, and ca. 25 DD in snow-fed rivers (Figure 6A). A similar result was found for the 2006 and 2015 heatwaves (Figure 6B), although fewer DD cumulated for low-land rivers due to the shorter length of the heatwave (July 2006: ca. 90, 20, and 20 DD for low-land, regulated and snow-fed rivers respectively; July 2015: ca. 80, 25, and 30 DD for the same river categories). The behavior is clear: heatwave effects were evident and extreme in low-land rivers, while being significantly mitigated in regulated and snow-fed rivers. This result suggests that the general thermal sensitivity of the three river categories as described by Piccolroaz et al. [37] is expected to be valid in the presence of extreme weather events. In addition to that, statistically significant long-term trends in DD were identified, in particular for the JJA period (Figure 6A and Table 3). The extraordinary high DD values cumulating during heatwaves relative to long-term warming trends (Figure 6A,B) effectively illustrate how heatwaves may act as a pulse disturbance in the case of the highly responsive low-land rivers. Since we believe that the use of linear trends to describe long-term dynamics may obscure the identification and interpretation of interannual fluctuations or regime shifts [70], we also report the five-year moving average line. 

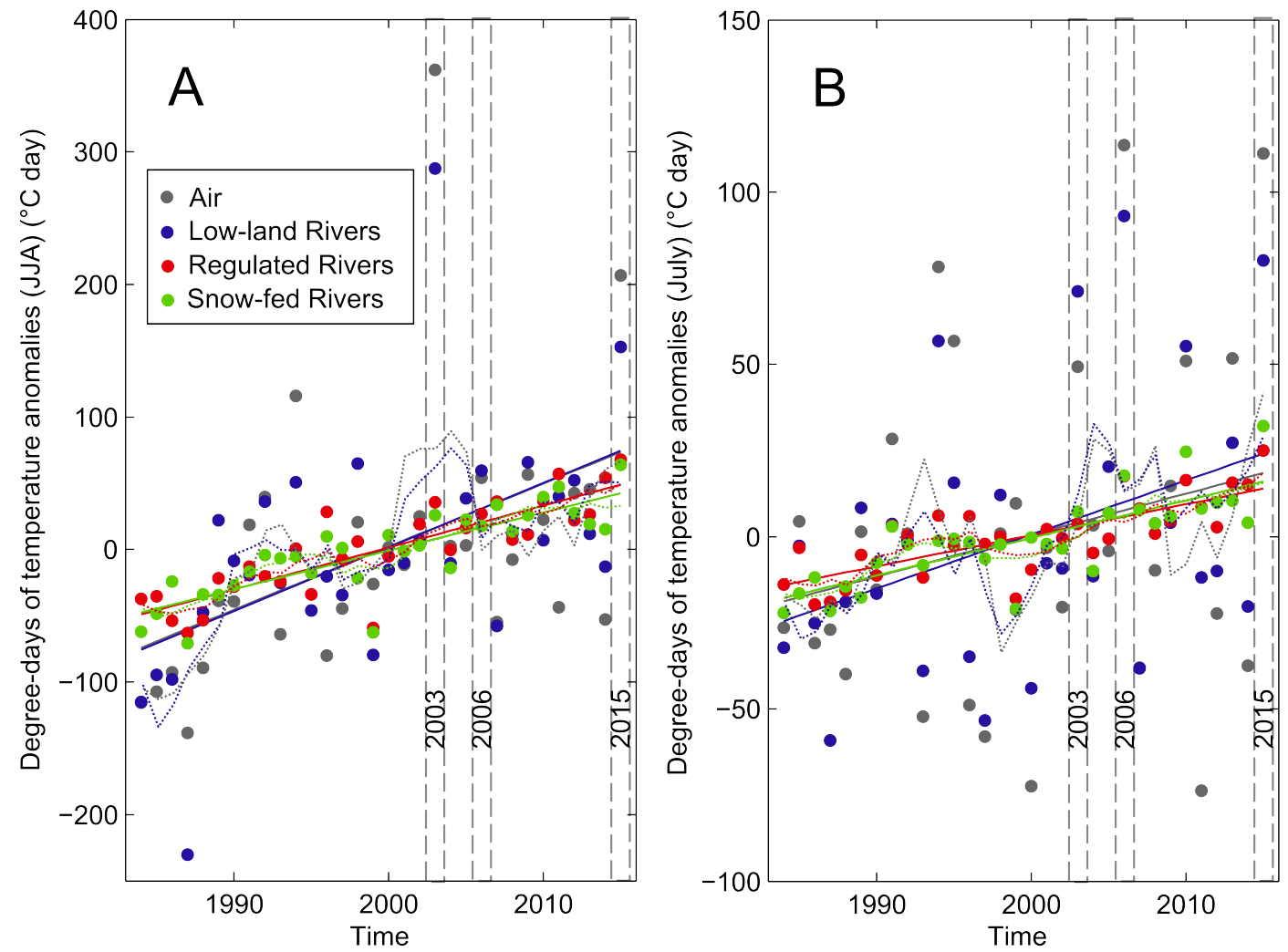

Figure 6. Cumulative degree-days of average temperature anomalies (dots) in JJA (A) and July (B). The long-term linear trends (continuous lines, see Table 3 for significance values) and the five-year moving average lines (dotted lines) are also plotted.

Table 3. Results from linear regression (slope $m$, coefficient of determination $R^{2}$, and significance level $p$ of the F test) used to evaluate long-term trends of DD for the period JJA and for July. Linear regression is considered statistically significant for $p$-value $<0.01$.

\begin{tabular}{lccc}
\hline & $\begin{array}{c}m \\
\left({ }^{\circ} \mathrm{C} \text { Day/Year }\right)\end{array}$ & $\begin{array}{c}\boldsymbol{R}^{2} \\
(-)\end{array}$ & $\begin{array}{c}p \text {-Value } \\
(-)\end{array}$ \\
\hline Air & & & \\
JJA & 4.76 & 0.22 & $<0.01$ \\
J & 1.20 & 0.06 & 0.19 \\
Low-land rivers & & & \\
JJA & 4.84 & 0.28 & $<0.01$ \\
J & 1.57 & 0.15 & 0.03 \\
Regulated rivers & & & \\
JJA & 3.16 & 0.72 & $<0.01$ \\
J & 0.90 & 0.57 & $<0.01$ \\
Snow-fed rivers & & & \\
JJA & 2.89 & 0.70 & $<0.01$ \\
J & 1.09 & 0.64 & $<0.01$ \\
\hline
\end{tabular}

\section{Discussion and Conclusions}

The analysis presented here showed the existence of a large-scale regional coherence of RWT in Switzerland when analyzing rivers with the same hydrological (and consequently thermal) regime, despite the analyzed rivers being varied in terms of catchment area, elevation, and orientation (see Table 1 and Figure 1). This confirmed and extended previous studies e.g., [40] by specifically addressing the response of RWT to extreme climatic events. The analysis of the heatwave events clearly indicated that low-land rivers were extremely sensitive to changes in AT in the presence of extreme events, 
while snow-fed and regulated rivers showed a marked thermally resilient behavior, confirming the thermal response of these three river categories under typical weather conditions [37]. The results were also in agreement with recent findings obtained analyzing a similar dataset [60], but considering indicators based on sub-daily thermal variability to differentiate between rivers affected or not by hydropower releases. For snow-fed rivers, we concluded that heatwave pulses are mitigated by cool water inputs from glacier/snowfield meltwaters or may even cause cold water anomalies in summer due to greater cool water inputs, as observed during the 2003 heatwave (see Figures 2 and 3 ). Cool water releases from reservoirs or hydraulic diversions at higher elevations also mitigated the thermal response to heatwaves in regulated rivers. Fully equivalent results were obtained analyzing the anomalies of daily minimum and maximum RWT (not shown), which are often considered as significant indexes when investigating the freshwater ecosystems e.g., [71]. A schematic representation of how the three different river categories considered in this study respond to heatwaves is shown in Figure 7.
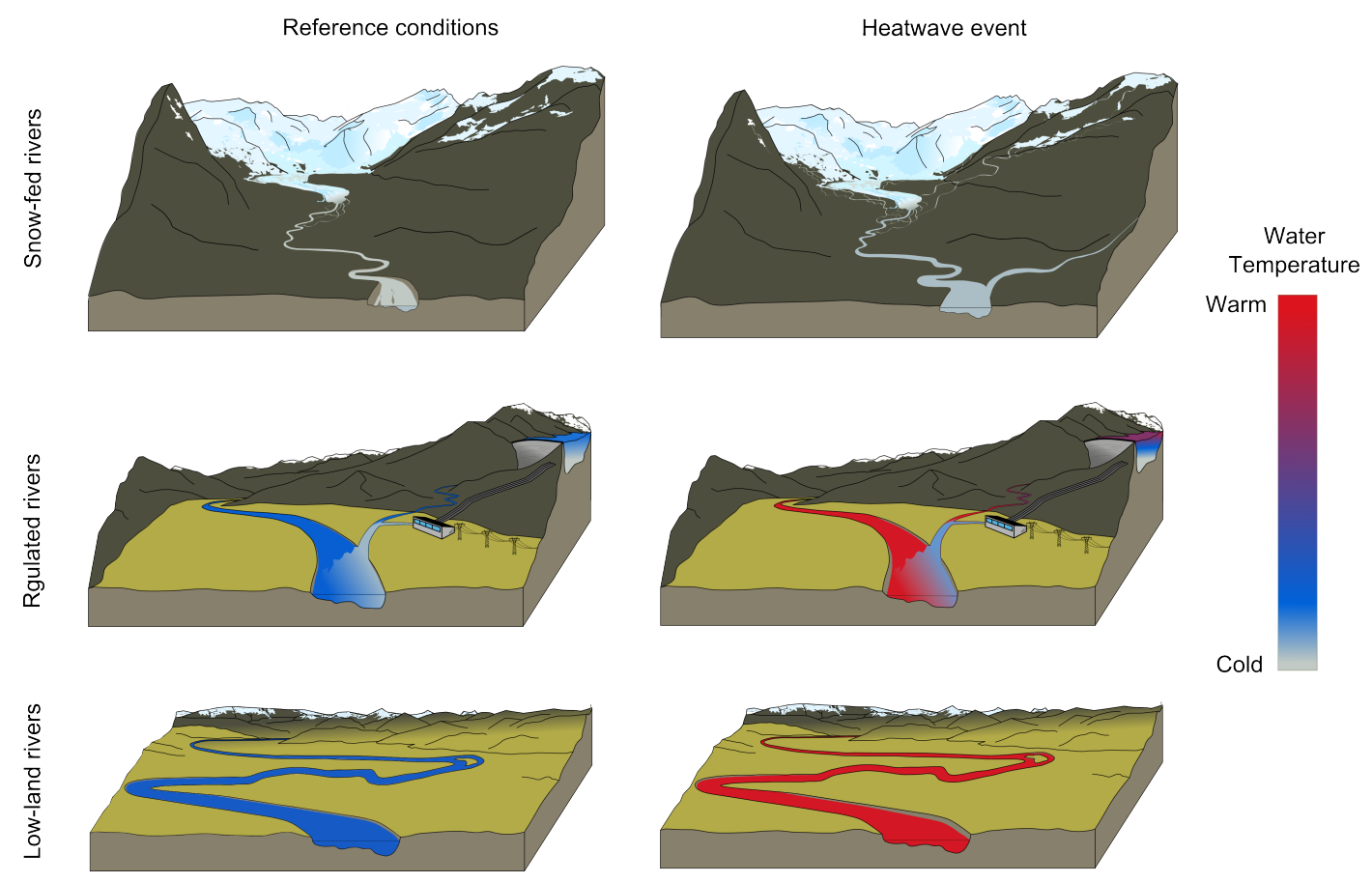

Figure 7. Qualitative description of the different hydrological categories of rivers investigated in this work and of their different response to heatwaves: 'snow-fed' rivers comprise natural rivers at high altitude and at short distance downstream of a glacier or snowfield; 'regulated' rivers flow along mountain valley floors and are affected by water releases from higher altitudes through anthropogenic regulations; 'low-land' rivers are rivers not significantly affected by anthropogenic flow releases, located at low altitudes, and characterized by large catchment areas. Snow-fed and regulated rivers are thermally resilient rivers showing a mild response to heatwaves thanks to cold water releases from high altitudes. Low-land rivers are thermally reactive rivers showing a significant response to heatwave events.

One may wonder whether the similar behavior between regulated and snow-fed rivers is due to the fact that regulated rivers are generally located in mountainous regions where a contribution of snowmelting to spring/summer streamflow is present. However, Figure 8 provides evidence of substantial differences between the two river categories. Figure 8A shows the relationship existing between river station elevation and upstream catchment surface area, for the three river categories. Two distinctive clustering patterns are clearly distinguishable between snow-fed rivers and low-land and regulated rivers. Snow-fed river gauge stations were characterized by significantly smaller 
catchment areas $(40 \times$ smaller, on average) and higher elevations $(3 \times$ higher, on average) compared to the other two groups of rivers. Geographic features of regulated rivers were clearly different from those of snow-fed rivers, but were comparable to those of low-land rivers. Additionally, Figure 8B shows a similar clustering when looking at the flow duration curves of the three groups of rivers. In this case, regulated and snow-fed rivers showed marked differences in their hydrological regime, the former class of rivers behaving similarly to the group of low-land rivers. In particular, snow-fed rivers showed larger variability of streamflow during the year, as a result of the alternation of high flows in spring/summer due to snowmelt and extremely low flows in winter when precipitation is snow and snowmelt is low. These substantial differences indicate that the thermal behavior of regulated rivers is actually not controlled by the same factors as in snow-fed rivers, but that other dynamics, such as cold water releases from high-altitude reservoirs or hydraulic diversions, are fundamental. As a side comment, we acknowledge that the analysis of snow-fed rivers may suffer from the availability of only two long-term river stations. For this reason, in the analysis provided in Figure 8B, we supported the results by adding the information from other stations (see Table 1) with a 30-year record of SF but shorter records of RWT data, which prevented their use in the analysis presented in the previous section.
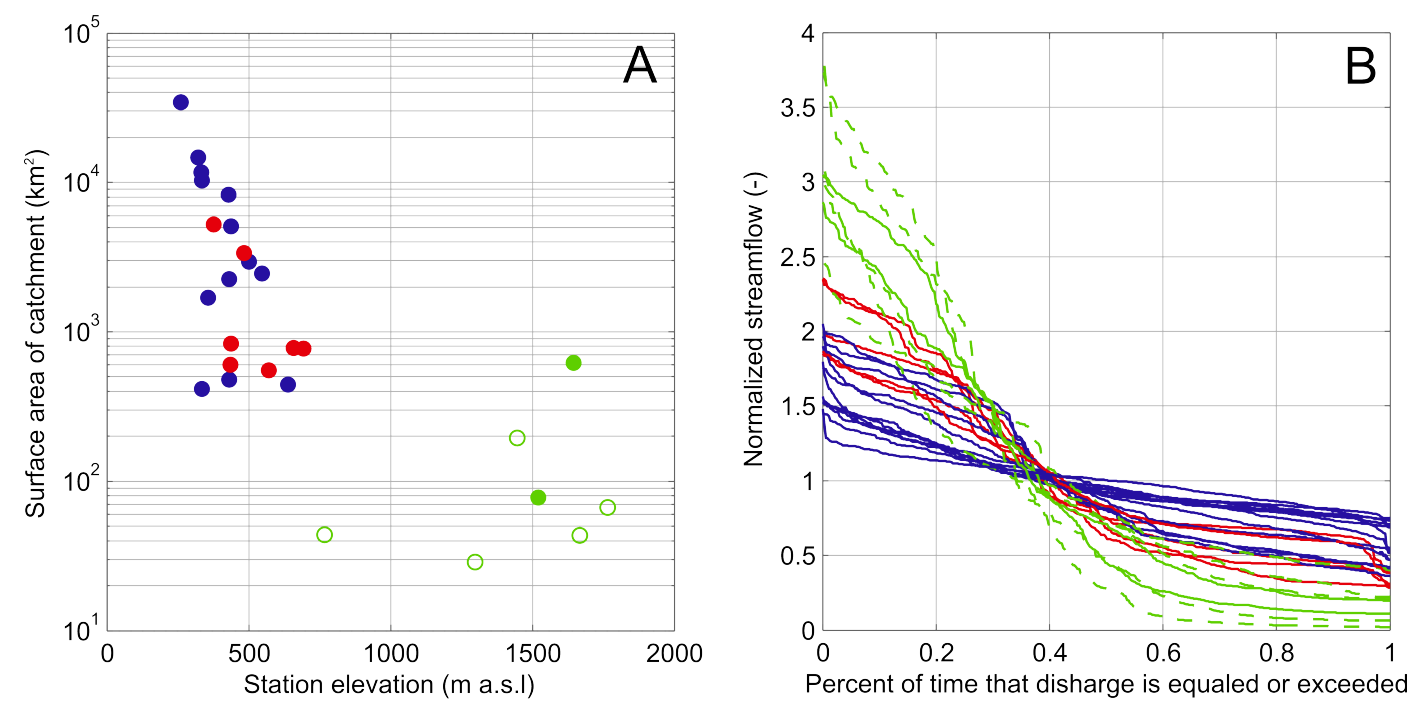

- Low-land rivers Regulated rivers o Snow-fed rivers

Figure 8. Relationship between river station elevation and upstream catchment surface area (A) and flow duration curves (B) for the three river categories. Note that flow duration curves are evaluated in terms of normalized streamflow evaluated for the climatological year (each line is represented by 365 points). Empty symbols and dashed lines refer to river stations not used in the heatwave analysis because they have less than 30 years of RWT data (see Table 1).

In their original river classification, Piccolroaz et al. [37] categorized low-land rivers and lake outlets into two different river groups. This was motivated by clear differences in the seasonal patterns of SF, while thermal reactiveness to changes in AT was similar in the two cases. Preliminary analysis (not shown) evidenced fully comparable behavior of these two river categories also in the case of thermal response to extreme heat events, thus making it convenient to group the two river types into one category. This further confirms the secondary role of SF in modulating RWT, which clearly emerged from the analysis presented in Section 3, especially in the cases of regulated and snow-fed rivers. Although it is difficult to infer more detailed conclusions based on the present analysis, what emerged was a secondary effect of the variation of the thermal inertia of the river due to changes in SF. However, we suggest that it is not just SF but also the temperature of upstream water fluxes that should be considered as a control of downstream RWT, both of which are likely to undergo significant changes in 
timing and magnitude under climate change especially in regulated and snow-fed rivers. According to previous studies e.g., [72-74], thermal cooling effects in snow-fed rivers will likely dampen with global, long-term glacier loss and may even flip to thermal warming effects as observed in low-land rivers. Although quantifying RWT response to future heatwave events is beyond the scope of the present study, the above considerations suggest that reliable hydrological simulations are necessary for making trustworthy projections under climate change scenarios. This should be carefully considered in defining river management and conservation planning strategies, especially in regulated river where, depending on the location and depth of the water intake, water releases could be used to effectively mitigate warm stream temperature in summer [30,75-78].

Warming RWTs are already causing shifts in the distribution and abundance of freshwater organisms by altering water quality, stressing upper thermal limits, and increasing the invasion potential of non-native species, particularly taxa that are temperature eurytolerant [79-81]. As rivers become warmer from climate change, the effect of an extreme heatwave event (even less intense, as 2006 relative to 2003) as a pulse disturbance has higher probability of causing an ecosystem state change $[48,82]$, providing the stimulus for ecosystems to cross ecological thresholds into novel, and potentially irreversible, ecosystem states. The extreme heatwave of 2003 has been posited to have caused ecosystem shifts in some rivers [79,81], although relatively few studies have explicitly examined the effects of heatwaves on river ecosystems e.g., [38,53,60,80]. In this context, the results of the present analysis point to the need for advancing our knowledge on how pulse heatwave effects on thermal regimes may influence the ecology of rivers, and how these pulse events act as press disturbances in the presence of ongoing climate warming.

Author Contributions: A.S., S.P., and M.T conceived the work. S.P. performed the analysis. All authors contributed to analyze the results, writing and approved the final version of the manuscript.

Funding: This research received no external funding.

Acknowledgments: Water temperature and streamflow data were kindly provided by the Swiss Federal Office of the Environment (BAFU), and meteorological data by the Swiss Meteorological Institute (MeteoSchweiz). The data can be requested through the data service form on the corresponding websites: http:/ / www.bafu.admin.ch and http:/ / www.meteoswiss.admin.ch, respectively.

Conflicts of Interest: The authors declare no conflict of interest.

\section{References}

1. Stefan, H.G.; Preud'homme, E.B. Stream temperature estimation from air temperature. JAWRA J. Am. Water Resour. Assoc. 1993, 29, 27-45. [CrossRef]

2. Mohseni, O.; Stefan, H. Stream temperature/air temperature relationship: A physical interpretation. J. Hydrol. 1999, 218, 128-141. [CrossRef]

3. Webb, B.W.; Clack, P.D.; Walling, D.E. Water-air temperature relationships in a Devon river system and the role of flow. Hydrol. Process. 2003, 17, 3069-3084. [CrossRef]

4. Caissie, D. The thermal regime of rivers: A review. Freshw. Biol. 2006, 51, 1389-1406. [CrossRef]

5. Kothandaraman, V. Air-water temperature relationship in Illinois River. JAWRA J. Am. Water Resour. Assoc. 1972, 8, 38-45. [CrossRef]

6. Mohseni, O.; Stefan, H.; Erickson, T. A nonlinear regression model for weekly stream temperatures. Water Resour. Res. 1998, 34, 2685-2692. [CrossRef]

7. Erickson, T.R.; Stefan, H.G. Linear air/water temperature correlations for streams during open water periods. J. Hydrol. Eng. 2000, 5, 317-321. [CrossRef]

8. Isaak, D.J.; Luce, C.H.; Rieman, B.E.; Nagel, D.E.; Peterson, E.E.; Horan, D.L.; Parkes, S.; Chandler, G.L. Effects of climate change and wildfire on stream temperatures and salmonid thermal habitat in a mountain river network. Ecol. Appl. 2010, 20, 1350-1371. [CrossRef] [PubMed]

9. van Vliet, M.T.H.; Ludwig, F.; Zwolsman, J.J.G.; Weedon, G.P.; Kabat, P. Global river temperatures and sensitivity to atmospheric warming and changes in river flow. Water Resour. Res. 2011, 47. [CrossRef] 
10. Arismendi, I.; Safeeq, M.; Johnson, S.; Dunham, J.; Haggerty, R. Can air temperature be used to project influences of climate change on stream temperature? Environ. Res. Lett. 2014, 9, 084015. [CrossRef]

11. Toffolon, M.; Piccolroaz, S. A hybrid model for river water temperature as a function of air temperature and discharge. Environ. Res. Lett. 2015, 10, 114011. [CrossRef]

12. Sohrabi, M.M.; Benjankar, R.; Tonina, D.; Wenger, S.J.; Isaak, D.J. Estimation of daily stream water temperatures with a Bayesian regression approach. Hydrol. Process. 2017, 31, 1719-1733. [CrossRef]

13. Diffenbaugh, N.; Field, C. Changes in ecologically critical terrestrial climate conditions. Science 2013, 341, 486-492. [CrossRef] [PubMed]

14. Krasting, J.P.; Broccoli, A.J.; Dixon, K.W.; Lanzante, J.R. Future Changes in Northern Hemisphere Snowfall. J. Clim. 2013, 26, 7813-7828. [CrossRef]

15. Brown, L.E.; Hannah, D.M.; Milner, A.M. Hydroclimatological influences on water column and streambed thermal dynamics in an alpine river system. J. Hydrol. 2006, 325, 1-20. [CrossRef]

16. Leach, J.A.; Moore, R.D. Winter stream temperature in the rain-on-snow zone of the Pacific Northwest: Influences of hillslope runoff and transient snow cover. Hydrol. Earth Syst. Sci. 2014, 18, 819-838. [CrossRef]

17. Lisi, P.J.; Schindler, D.E.; Cline, T.J.; Scheuerell, M.D.; Walsh, P.B. Watershed geomorphology and snowmelt control stream thermal sensitivity to air temperature. Geophys. Res. Lett. 2015, 42, 3380-3388. [CrossRef]

18. Luce, C.; Staab, B.; Kramer, M.; Wenger, S.; Isaak, D.; McConnell, C. Sensitivity of summer stream temperatures to climate variability in the Pacific Northwest. Water Resour. Res. 2014, 50, 3428-3443. [CrossRef]

19. Isaak, D.J.; Young, M.K.; Luce, C.H.; Hostetler, S.W.; Wenger, S.J.; Peterson, E.E.; Ver Hoef, J.M.; Groce, M.C.; Horan, D.L.; Nagel, D.E. Slow climate velocities of mountain streams portend their role as refugia for cold-water biodiversity. Proc. Natl. Acad. Sci. USA 2016, 113, 4374-4379. [CrossRef] [PubMed]

20. Tague, C.; Farrell, M.; Grant, G.; Lewis, S.; Rey, S. Hydrogeologic controls on summer stream temperatures in the McKenzie River basin, Oregon. Hydrol. Process. 2007, 21, 3288-3300. [CrossRef]

21. Salmaso, F.; Quadroni, S.; Gentili, G.; Crosa, G. Thermal regime of a highly regulated Italian River (Ticino River) and implications for aquatic communities. J. Limnol. 2017, 76, 23-33. [CrossRef]

22. Taylor, C.A.; Stefan, H.G. Shallow groundwater temperature response to climate change and urbanization. J. Hydrol. 2009, 375, 601-612. [CrossRef]

23. Ding, J.; Jiang, Y.; Fu, L.; Liu, Q.; Peng, Q.; Kang, M. Impacts of Land Use on Surface Water Quality in a Subtropical River Basin: A Case Study of the Dongjiang River Basin, Southeastern China. Water 2015, 7, 4427-4445. [CrossRef]

24. Moore, R.D.; Spittlehouse, D.L.; Story, A. Riparian microclimate and stream temperature response to forest harvesting: A Review. JAWRA J. Am. Water Resour. Assoc. 2005, 41, 813-834. [CrossRef]

25. Garner, G.; Malcolm, I.A.; Sadler, J.P.; Hannah, D.M. The role of riparian vegetation density, channel orientation and water velocity in determining river temperature dynamics. J. Hydrol. 2017, 553, 471-485. [CrossRef]

26. Eunsun, E.L.; Edward, J.N. Longitudinal trends in regulated rivers: A review and synthesis within the context of the serial discontinuity concept. Environ. Rev. 2013, 21, 136-148.

27. Arora, R.; Toffolon, M.; Tockner, K.; Venohr, M. Thermal discontinuities along a lowland river: The importance of urban areas and lakes. J. Hydrol. 2018, 564, 811-823. [CrossRef]

28. Lowney, C.L. Stream temperature variation in regulated rivers: Evidence for a spatial pattern in daily minimum and maximum magnitudes. Water Resour. Res. 2000, 36, 2947-2955. [CrossRef]

29. Ward, J.V.; Stanford, J.A. Ecological connectivity in alluvial river ecosystems and its disruption by flow regulation. Regul. River 1995, 11, 105-119. [CrossRef]

30. Olden, J.D.; Naiman, R.J. Incorporating thermal regimes into environmental flows assessments: Modifying dam operations to restore freshwater ecosystem integrity. Freshw. Biol. 2010, 55, 86-107. [CrossRef]

31. Cai, H.; Piccolroaz, S.; Huang, J.; Liu, Z.; Liu, F.; Toffolon, M. Quantifying the impact of the Three Gorges Dam on the thermal dynamics of the Yangtze River. Environ. Res. Lett. 2018, 13, 054016. [CrossRef]

32. Raptis, C.E.; van Vliet, M.T.H.; Pfister, S. Global thermal pollution of rivers from thermoelectric power plants. Environ. Res. Lett. 2016, 11, 104011. [CrossRef]

33. Hester, E.T.; Doyle, M.W. Human Impacts to River Temperature and Their Effects on Biological Processes: A Quantitative Synthesis. JAWRA J. Am. Water Resour. Assoc. 2011, 47, 571-587. [CrossRef]

34. Webb, B.W.; Nobilis, F. Long-term changes in river temperature and the influence of climatic and hydrological factors. Hydrol. Sci. J. 2007, 52, 74-85. [CrossRef] 
35. Kelleher, C.; Wagener, T.; Gooseff, M.; McGlynn, B.; McGuire, K.; Marshall, L. Investigating controls on the thermal sensitivity of Pennsylvania streams. Hydrol. Process. 2012, 26, 771-785. [CrossRef]

36. Mayer, T. Controls of summer stream temperature in the Pacific Northwest. J. Hydrol. 2012, 475, 323-335. [CrossRef]

37. Piccolroaz, S.; Calamita, E.; Majone, B.; Gallice, A.; Siviglia, A.; Toffolon, M. Prediction of river water temperature: A comparison between a new family of hybrid models and statistical approaches. Hydrol. Process. 2016, 30, 3901-3917. [CrossRef]

38. Woodward, G.; Bonada, N.; Brown, L.; Death, R.; Durance, I.; Gray, C.; Hladyz, S.; Ledger, M.; Milner, A.; Ormerod, S.; et al. The effects of climatic fluctuations and extreme events on running water ecosystems. Philos. Trans. R. Soc. B 2016, 371. [CrossRef] [PubMed]

39. Robinson, P.J. On the Definition of a Heat Wave. J. Appl. Meteorol. 2001, 40, 762-775. [CrossRef]

40. Hari, R.E.; Livingstone, D.M.; Siber, R.; Burkhardt-Holm, P.; Guettinger, H. Consequences of climatic change for water temperature and brown trout populations in Alpine rivers and streams. Glob. Chang. Biol. 2006, 12, 10-26. [CrossRef]

41. Kaushal, S.S.; Likens, G.E.; Jaworski, N.A.; Pace, M.L.; Sides, A.M.; Seekell, D.; Belt, K.T.; Secor, D.H.; Wingate, R.L. Rising stream and river temperatures in the United States. Front. Ecol. Environ. 2010, 8, 461-466. [CrossRef]

42. Isaak, D.J.; Wollrab, S.; Horan, D.; Chandler, G. Climate change effects on stream and river temperatures across the northwest U.S. from 1980-2009 and implications for salmonid fishes. Clim. Chang. 2012, 113, 499-524. [CrossRef]

43. Orr, H.G.; Simpson, G.L.; des Clers, S.; Watts, G.; Hughes, M.; Hannaford, J.; Dunbar, M.J.; Laizé, C.L.R.; Wilby, R.L.; Battarbee, R.W.; et al. Detecting changing river temperatures in England and Wales. Hydrol. Process. 2015, 29, 752-766. [CrossRef]

44. Meehl, G.A.; Tebaldi, C. More intense, more frequent, and longer lasting heat waves in the 21st century. Science 2004, 305, 994-997. [CrossRef] [PubMed]

45. Beniston, M. The 2003 heat wave in Europe: A shape of things to come? An analysis based on Swiss climatological data and model simulations. Geophys. Res. Lett. 2004, 31. [CrossRef]

46. Christidis, N.; Jones, G.S.; Stott, P.A. Dramatically increasing chance of extremely hot summers since the 2003 European heatwave. Nat. Clim. Chang. 2014, 5, 46-50. [CrossRef]

47. Rahmstorf, S.; Coumou, D. Increase of extreme events in a warming world. Proc. Natl. Acad. Sci. USA 2011, 108, 17905-17909. [CrossRef] [PubMed]

48. Jentsch, A.; Kreyling, J.; Beierkuhnlein, C. A new generation of climate-change experiments: Events, not trends. Front. Ecol. Environ. 2007, 5, 365-374. [CrossRef]

49. Hegerl, G.C.; Hanlon, H.; Beierkuhnlein, C. Climate science: Elusive extremes. Nat. Geosci. 2011, 4, 142-143. [CrossRef]

50. O'Gorman, E.J.; Pichler, D.E.; Adams, G.; Benstead, J.P.; Cohen, H.; Craig, N.; Cross, W.F.; Demars, B.O.; Friberg, N.; Gíslason, G.M.; et al. Chapter 2-Impacts of Warming on the Structure and Functioning of Aquatic Communities: Individual- to Ecosystem-Level Responses. In Global Change in Multispecies Systems Part 2; Woodward, G., Jacob, U., O'Gorman, E.J., Eds.; Academic Press: Cambridge, MA, USA, 2012; Volume 47, pp. 81-176.

51. Diez, J.M.; D’Antonio, C.M.; Dukes, J.S.; Grosholz, E.D.; Olden, J.D.; Sorte, C.J.; Blumenthal, D.M.; Bradley, B.A.; Early, R.; Ibáñez, I.; et al. Will extreme climatic events facilitate biological invasions? Front. Ecol. Environ. 2012, 10, 249-257. [CrossRef]

52. Mouthon, J.; Daufresne, M. Effects of the 2003 heatwave and climatic warming on mollusc communities of the Saône: A large lowland river and of its two main tributaries (France). Glob. Chang. Biol. 2006, 12, 441-449. [CrossRef]

53. Mouthon, J.; Daufresne, M. Resilience of mollusc communities of the River Saone (eastern France) and its two main tributaries after the 2003 heatwave. Freshw. Biol. 2015, 60, 2571-2583. [CrossRef]

54. Russo, S.; Sillmann, J.; Fischer, E.M. Top ten European heatwaves since 1950 and their occurrence in the coming decades. Environ. Res. Lett. 2015, 10, 124003. [CrossRef]

55. de Montmollin, F.; Parodi, A. Température des Cours d'eau Suisses; Mitteilung Nr. 12 der Landeshydrologie und -geologie. The Service Hydrologique et Géologique National: Bern, Switzerland, 1990.

56. Jakob, A. Temperaturen in Schweizer Fliessgewässern. Gas Wasser Abwasser 2010, 3, 221-231.

57. Vanzo, D.; Siviglia, A.; Carolli, M.; Zolezzi, G. Characterization of sub-daily thermal regime in alpine rivers: Quantification of alterations induced by hydropeaking. Hydrol. Process. 2016, 30, 1052-1070. [CrossRef] 
58. Livingstone, D.M.; Lotter, A.F.; Kettle, H. Altitude-dependent differences in the primary physical response of mountain lakes to climatic forcing. Limnol. Oceanogr. 2005, 50, 1313-1325. [CrossRef]

59. Carolli, M.; Vanzo, D.; Siviglia, A.; Zolezzi, G.; Bruno, M.C.; Alfredsen, K. A simple procedure for the assessment of hydropeaking flow alterations applied to several European streams. Aquat. Sci. 2015, 77, 639-653. [CrossRef]

60. Feng, M.; Zolezzi, G.; Pusch, M. Effects of thermopeaking on the thermal response of alpine river systems to heatwaves. Sci. Total Environ. 2018, 612, 1266-1275. [CrossRef] [PubMed]

61. Upperman, C.; Parker, J.; Jiang, C.; He, X.; Murtugudde, R.; Sapkota, A. Frequency of Extreme Heat Event as a Surrogate Exposure Metric for Examining the Human Health Effects of Climate Change. PLoS ONE 2015, 10. [CrossRef] [PubMed]

62. Luterbacher, J.; Dietrich, D.; Xoplaki, E.; Grosjean, M.; Wanner, H. European Seasonal and Annual Temperature Variability, Trends, and Extremes Since 1500. Science 2004, 303, 1499-1503. [CrossRef] [PubMed]

63. Hansen, J.; Sato, M.; Ruedy, R. Perception of climate change. Proc. Natl. Acad. Sci. USA 2012, 109, E2415-E2423. [CrossRef] [PubMed]

64. Schär, C.; Vidale, P.; Lüthi, D.; Frei, C.; Häberli, C.; Liniger, M.; Appenzeller, C. The role of increasing temperature variability in European summer heatwaves. Nature 2004, 427, 332-336. [CrossRef] [PubMed]

65. Hansen, J.; Ruedy, R.; Glascoe, J.; Sato, M. GISS analysis of surface temperature change. J. Geophys. Res. 1999, 104, 30997-31022. [CrossRef]

66. Begert, M.; Schlegel, T.; Kirchhofer, W. Homogeneous temperature and precipitation series of Switzerland from 1864 to 2000. Int. J. Climatol. 2005, 25, 65-80. [CrossRef]

67. Allan, J.D. Stream Ecology, Structure and Function of Running Waters; Springer: Dordrecht, The Netherlands, 1995.

68. Tetzlaff, D.; Soulsby, C.; Youngson, A.F.; Gibbins, C.; Bacon, P.J.; Malcolm, I.A.; Langan, S. Variability in stream discharge and temperature: A preliminary assessment of the implications for juvenile and spawning Atlantic salmon. Hydrol. Earth Syst. Sci. 2005, 9, 193-208. [CrossRef]

69. Chezik, K.; Lester, N.; Venturelli, P. Fish growth and degree-days I: Selecting a base temperature for a within-population study. Can. J. Fish. Aquat.Sci. 2014, 71, 47-55. [CrossRef]

70. Piccolroaz, S.; Healey, N.C.; Lenters, J.D.; Schladow, S.G.; Hook, S.J.; Sahoo, G.B.; Toffolon, M. On the predictability of lake surface temperature using air temperature in a changing climate: A case study for Lake Tahoe (USA). Limnol. Oceanogr. 2018, 63, 243-261. [CrossRef]

71. Arismendi, I.; Johnson, S.; Dunham, J.; Haggerty, R. Descriptors of natural thermal regimes in streams and their responsiveness to change in the Pacific Northwest of North America. Freshw. Biol. 2013, 58, 880-894. [CrossRef]

72. Stahl, K.; Moore, R.D. Influence of watershed glacier coverage on summer streamflow in British Columbia, Canada. Water Resour. Res. 2006, 42. [CrossRef]

73. Moore, R.D.; Fleming, S.W.; Menounos, B.; Wheate, R.; Fountain, A.; Stahl, K.; Holm, K.; Jakob, M. Glacier change in western North America: Influences on hydrology, geomorphic hazards and water quality. Hydrol. Process. 2009, 23, 42-61. [CrossRef]

74. Kobierska, F.; Jonas, T.; Magnusson, J.; Zappa, M.; Bavay, M.; Bosshard, T.; Paul, F.; Bernasconi, S.M. Climate change effects on snow melt and discharge of a partly glacierized watershed in Central Switzerland (SoilTrec Critical Zone Observatory). Appl. Geochem. 2011, 26, S60-S62. [CrossRef]

75. Neumann, D.W.; Zagona, E.A.; Rajagopalan, B. A Decision Support System to Manage Summer Stream Temperatures ${ }^{1}$. JAWRA J. Am. Water Resour. Assoc. 2006, 42, 1275-1284. [CrossRef]

76. Yates, D.; Galbraith, H.; Purkey, D.; Huber-Lee, A.; Sieber, J.; West, J.; Herrod-Julius, S.; Joyce, B. Climate warming, water storage, and Chinook salmon in California's Sacramento Valley. Clim. Chang. 2008, 91, 335-350. [CrossRef]

77. Null, S.; Ligare, S.; Viers, J. A Method to Consider Whether Dams Mitigate Climate Change Effects on Stream Temperatures. J. Am. Water Resour. Assoc. 2013, 49, 1456-1472. [CrossRef]

78. Benjankar, R.; Tonina, D.; McKean, J.A.; Sohrabi, M.M.; Chen, Q.; Vidergar, D. Dam operations may improve aquatic habitat and offset negative effects of climate change. J. Environ. Manag. 2018, 213, 126 -134. [CrossRef] [PubMed]

79. Daufresne, M.; Bady, P.; Fruget, J.F. Impacts of global changes and extreme hydroclimatic events on macroinvertebrate community structures in the French Rhône River. Oecologia 2007, 151, 544-559. [CrossRef] [PubMed]

80. Mouthon, J.; Daufresne, M. Long-term changes in mollusc communities of the Ognon river (France) over a 30-year period. Fundam. Appl. Limnol. Arch. Hydrobiol. 2010, 178, 67-79. [CrossRef] 
81. Sorte, C.J.; Ibanez, I.; Blumenthal, D.M.; Molinari, N.A.; Miller, L.P.; Grosholz, E.D.; Diez, J.M.; D'Antonio, C.M.; Olden, J.D.; Jones, S.J.; et al. Poised to prosper? A cross-system comparison of climate change effects on native and non-native species performance. Ecol. Lett. 2013, 16, 261-270. [CrossRef] [PubMed]

82. Scheffer, M.; Carpenter, S.; Foley, J.A.; Folke, C.; Walker, B. Catastrophic shifts in ecosystems. Nature 2001, 413, 591-596. [CrossRef] [PubMed]

(C) 2018 by the authors. Licensee MDPI, Basel, Switzerland. This article is an open access article distributed under the terms and conditions of the Creative Commons Attribution (CC BY) license (http://creativecommons.org/licenses/by/4.0/). 